\title{
The Need for Trust and Ethics in the Digital Age - Sunshine and Shadows in the FinTech World*
}

\author{
János Müller - Ádám Kerényi
}

In the wake of the international financial crisis, digital financial and FinTech services have emerged as part of the fourth industrial revolution. These services, which are generally supported and welcomed by consumers, have now reached a stage where they are able to disrupt traditional financial structures. In the past, the role of FinTech startups was considered marginal and risk-free both by banks, which were busy restoring trust and optimising their operations, and by regulators and supervisors. However, as they have spread at a revolutionary pace, FinTech now entails several types of risk to financial stability and represents a serious threat. In order to address potential problems relating to financial stability, the need has emerged to regulate FinTech at the national and international levels, including the management of the body of data accumulated and used by FinTech companies. A situation has evolved in which three requirements should be met internationally and nationally: support for digital FinTech processes; a level playing field for incumbent banks and FinTech/BigTech companies; and the regulation of FinTechtype services at the international and national levels. Except for the first, these requirements have not been met to date, and expectations and codes of ethics and trust have gained prominence as workarounds. For that reason, the focus of our analysis is the importance of the requirements for trust and ethics in the banking sector, and the extent to which these requirements are enforced in the FinTech world. We present why it is becoming necessary to introduce codes of conduct, ethical standards and the exercise of due care in behaviour in order to build trust.

Journal of Economic Literature (JEL) codes: D74, G21, O33, N74

Keywords: trust, ethics, banks, FinTech, artificial intelligence, Regulatory Sandbox

* The papers in this issue contain the views of the authors which are not necessarily the same as the official views of the Magyar Nemzeti Bank.

Ádám Kerényi is a Researcher at the Institute of World Economics of the Hungarian Academy of Sciences.

E-mail: kerenyi.adam@krtk.mta.hu

János Müller is an Economist and Chief Advisor of the Hungarian Banking Association.

E-mail: mullerj1@t-online.hu

We are grateful to the two anonymous reviewers for their constructive comments and suggestions.

The Hungarian manuscript was received on 27 May 2019.

DOI: http://doi.org/10.33893/FER.18.4.534 


\section{Introduction}

For centuries, the banking sector has been an industry which operates on the basis of trust. As such, it has a wealth of experience in what it takes to build and maintain the trust of customers and the market, and the speed at which that trust can be lost. In light of the lessons learned from economic crises, rebuilding and recovering trust and security is a slow and difficult process. Obviously, all of this is influenced by the external conditions of banking operations: the institutional background, regulation and supervision, as well as the economic policy environment, i.e. the degree of consistency between monetary and fiscal policy. With the rise of a problem, a recession, a crisis or a bank failure, regulators respond immediately, identifying the 'wrongdoers and sinners', i.e. the banks, in order to reduce the losses at the sector level, and then to help the recovery and rebuild trust (Kerényi-Molnár 2017 and Kerényi-Müller 2019).

As an industry based on trust, the banking sector is governed by the fundamental operating principle of ensuring bank secrecy and the strict management of customer data, which is also regulated by law. Incumbent banks are also expected to apply ethical standards and requirements, and to ensure that these are enforced. At times when the economy works as it should, trust, confidence, ethics and a good business reputation represent value, and are means of achieving profitability. The question is how these expectations and professional requirements change and evolve in the course of a development process that is considered revolutionary, when the digital world has reached financial services and is forcing incumbent banks to transform their business models and when new operators and competitors are entering the market, as a result of which regulatory and supervisory arrangements are or should be changing as well. In that context, we examine the inevitable movements in the above factors at incumbent banks and FinTech/BigTech companies, and how trust is changing in the relationship between a bank and its customer. Is a level playing field provided for incumbent banks and the new digital service providers entering the market? Similar questions may also arise on the regulatory side. Every single activity of banks, including digital services, are regulated and may be controlled.

"How can we build trust in the digital age?" asked Roland Busch, a Member of the Managing Board of Siemens AG. "Digital technologies are changing our lives and economies. Artificial intelligence, big data analytics, blockchain and cloud technologies are improving our world in countless ways. But they bring new vulnerabilities. Digitalization and globalization are shifting paradigms and bringing new opportunities" (Busch 2018:1).

Can cross-border digital financial services be identified for regulatory purposes? Which jurisdiction will provide the background for trust: the country in which the FinTech company is registered, or the country in which the service is used? How can 
consumers build their trust in connection with the services of FinTech companies? Will digital competition lead to the transformation of incumbent banks' codes of ethics? Does it make sense to talk about FinTech trust and ethics? In this paper, we track these developments and provide an overview of the current status quo. In our inquiry, it is necessary that the relationship of the banking sector to trust and ethical conduct should first be addressed, followed by an analysis of that relationship in the FinTech world.

\section{Trust, confidence and ethics in the world of incumbent banks}

Life in modern societies involves a number of activities ${ }^{1}$ and services that depend greatly on trust and confidentiality. Without preserving secrets, the banking sector could not function; trust is based on an awareness that confidentiality exists. Over the centuries, stemming from the nature of its core operations, key requirements have emerged for the functioning of the banking sector: trust, security, confidence and ethical conduct towards customers.

All these features together underpin a bank's good business reputation. Trust in a bank's integrity and reliability can be developed if its decision-making and operations are governed by laws and detailed regulations, as well as by ethical and moral standards. Trust, strengthened by ethical conduct and a good business reputation are important preconditions for banks' successful operations, and their presence therefore represents value.

Trust is essentially a human predicament, developing on empirical grounds, during longer periods of smooth cooperation, or based on the experience of finding a solution to relatively difficult problems. One of its key preconditions is the maintenance of secrecy about matters of finance and wealth. The development of trust is also subject to some external conditions that apply independently of the financial institutions concerned, such as the legal environment, the laws governing financial institutions at large, the regulatory and supervisory arrangements in place, and also the level of financial awareness in a given country. Conditions referred to as internal include a bank's governance system, decision-making, risk management regulations, and procedures. Compliance with external and internal regulation is complemented by an element of building trust that is of critical relevance to our subject, i.e. the ethical conduct and integrity of bank employees.

\footnotetext{
${ }^{1}$ Consider, for instance, physicians, lawyers, or the spiritual participants of churches. In all of these cases, people share sensitive assets, concerns and sentiments with the parties they consult. Is there any treasure that is more precious than health? Can trust be greater than that of someone hoping to be healed by their physician? A believer expects sympathy and consolation from a pastor. Likewise, banks promise to safeguard families' industrious savings and reserves, and grant loans for the realisation of their plans. These are fields where confidentiality not only exists, but is expected and essential.
} 
Trust can be earned through work and thus only develops as a result of a longer process. The trust earned will provide for the hoped-for presumption of confidence. The value of these will be demonstrated when trust in a bank, or the banking sector as a whole, collapses as a result of some wrongdoing, error, or a negative external circumstance such as a recession or a crisis. Although trust takes a long time to build, it can collapse in a minute. The loss of confidence may take dramatic turns when it causes panic, with customers hyped into massive bank runs. As confirmed by numerous examples in banking history, the collapse of trust is toxic and contagious, and spreads extremely fast. ${ }^{2}$ Some of the building blocks of trust and confidence include past performance, excellent referrals, stability, profitability, a reliable and verifiable ownership structure, predictability, the quality of services and customer relations, and the longest possible continuous customer relations.

In order for the expected trust to develop, the relationship concerned must stand the test of distrust. The beginning of a relationship is fraught with distrust and suspicion by both parties. For example, both ex officio and in order to protect its existing depositors, a bank processing a credit application will be distrustful, i.e. it will collect a range of data from and about its prospective customer in an effort to conduct a risk analysis. In turn, customers will seek to ensure that their money or wealth is being committed to the care of a reliable institution.

The development of trust is thus the result of a process as part of which distrust, suspicion and confidence are balanced out. In addition to other important factors, the success of banks' business requires that balance be maintained for the longest possible time. In a bank functioning properly, legal compliance in the broad sense and ethical requirements coexist and work by mutually reinforcing each other. The order of priorities is also important, with precedence given to strict legal and internal regulations encompassing all processes in banking operations, integrated with the set of ethical standards. At the same time, the legal framework and regulations cannot cover all details of banking operations at all times. They are accompanied by the requirement for the application of ethical and moral standards in banks, and the need for professional integrity. There is a vast body of literature on bank ethics; for our purposes, it suffices to mention the generally accepted principles of ethical standards for banks. The literature sets out some eternal and mandatory requirements for incumbent banks' ethical conduct. These include, for instance, transparency, honesty, fairness, responsibility, predictability and respect for customers (Villa 2015:83).

\footnotetext{
${ }^{2}$ This is one of the reasons why the European Central Bank regularly reviews banks that carry systemic risk.
} 
Ethics ${ }^{3}$ and morals, as understood in the general sense, primarily concern core values and standards. Underlying both are intrinsic human values that are instrumental in guiding the individual in matters of good and bad, right and wrong, and equity and inequity. Hence the general understanding that ethics is a term capturing our moral standards that exist, whether explicitly or implicitly, even subconsciously, as a constant backdrop to our situational judgments, actions and decisions. ${ }^{4}$ The development of an individual's intrinsic values and ethical standards is influenced by cultural and religious traditions, the family environment and upbringing, the social environment established by laws and regulations, and not least by the set of requirements applied in the profession or workplace in question. For our purposes, the profession and activities concern the provision of banking services, and the flawless operation of the financial intermediary system.

The above implies that such standards ${ }^{5}$ can and do change as society and civilization evolve, while they also have pillars that have remained constant for millennia, which means that ethical standards have evolved into a sophisticated set of requirements over decades and centuries. The first of these is the requirement to comply with all valid rules in effect. To offer services and products that comply with the applicable provisions, including accurate and transparent information given to customers. This requirement is confirmed by the old adage that ethics begins where the law ends. Banking secrecy, data protection and confidentiality are prominent features of every bank's code of ethics. Another golden rule of bank ethics is the need to strive for the greatest possible degree of objectivity, by avoiding any form of influence or bias. The time factor also occupies a prominent role. This consideration may be stated briefly as the fact that in banking everything is urgent but nothing can be compelling. In today's fast-paced world, where business decisions and information can be transmitted electronically and digitally in a matter of minutes, the factor of accelerating time may lead to inaccuracies in risk assessment and errors in decisionmaking.

Looking back on the history of banks which lived through a series of economic cycles and crises, we can see that the questions of trust and ethics tend to take on increased prominence following periods of severe recession or crisis. In other words, there is a strong correlation between the trust in and the ethical requirements for banks on the one hand, and economic cycles on the other. These questions will

${ }^{3}$ Of Greek origin, the word 'ethics' is derived from 'éthos', meaning custom, tradition, form of behaviour. A frequent synonym of 'ethics' is 'morals', derived from Latin 'mores'. This means the right course of action, and irreproachable conduct. In everyday usage, the word 'morals' occurs more frequently.

${ }^{4}$ This is relevant because later on we will look for the ways in which these behavioural standards are manifested in the FinTech world.

${ }^{5}$ Consider the Bible, in the Old Testament where the law consisted in the Ten Commandments, including the eternal rule, "Thou shalt not steal". Over the course of time, the substance of that legal provision has undergone considerable changes. Today, its scope is no longer limited to an individual unlawfully taking an object; stealth includes tax fraud, while inappropriate bank contracts are also frequently seen by customers as stealth. 
become prominent and the focus of analysis when an economy and its banking sector are already past the worst of the crisis, and the process of resolution and recovery has been successful. That is when the restoration and reinforcement of trust is again on the banking agenda, accompanied by demands for ethical standards to that end. The changes in the ethical standards for banks in the aftermath of individual economic cycles is well illustrated by Koslowski's judgment of the situation: "the crisis in the financial markets unexpectedly turned a spotlight on the ethical aspects of financial markets and financial institutions as a topic of considerable interest to the wider public. [...] The financial crisis is not only a crisis of the economic system, but also a crisis of ethics for financial intermediaries, whose conduct threatened to turn the industry into a field of unmitigated self-enrichment" (Koslowski 2011:3).

After the eruption of the 2008 global financial crisis, we witnessed the development of a whole regulatory arsenal and an institutional architecture to strengthen the safe operations of the banking sector across the European Union. Suffice it to mention the broadened and strengthened powers of the European Central Bank (ECB), or the operations of the European Supervisory Authorities (ESA), the European Banking Authority (EBA), the European Insurance and Occupational Pensions Authority (EIOPA), the European Securities and Markets Authority (ESMA), the European Single Supervisory Mechanism, the European Funds and Mechanisms for Bank Resolution and Recovery, and the European Systemic Risk Board (ESRB). This was accompanied by ongoing efforts to build the Monetary Union, the Banking Union and the Capital Markets Union. Rules and measures were also adopted within national powers to guarantee the security of banking operations. The Hungarian practice was also aligned with these processes and objectives. Between 2009-2015, almost a hundred laws and regulations were adopted with relevance to the banking sector (consisting of 29 acts, 21 government decrees, and a large number of decrees by ministers and the Governor of the Magyar Nemzeti Bank [MNB]), while the applicable EU directives also had to be transposed into Hungarian law.

This (over-)regulation which is a typical feature of post-crisis periods was necessary to restore the stability of the banking sector, while also strengthening trust in the banking sector, both in Europe at large and in Hungary. For instance, compliance with capital requirements, and the situation of banks carrying systemic risk were monitored on a continuous basis. The banks resolved with government assistance were not allowed to undertake credit operations involving excessive risk. Wholesale funding and competition among banks resumed. One might be led to believe that all of this was sufficient for the recovery of trust. This was not the case. Almost as if following a set course, ethical and moral issues were raised. To cite another example from Hungary, as early as the beginning of 2010 the Code of Conduct for the banking sector was released with the primary aim of addressing specific areas 
in terms of conduct and ethics that legislation was not yet prepared to regulate at the time. The Code was amended in 2015, because in the meantime several of its provisions had been incorporated into the legal framework. The Code requires banks to enforce the following fundamental principles on a voluntary basis: transparency, regulatory compliance, and information symmetry.

"The lenders signing the Code [...] have an exclusive interest in supporting the development of their retail customers and thereby that of the Hungarian economy as a whole by means of fair competition and proper business conduct. They share the conviction that the present act of self-regulation, designed to complement the provisions of the Hungarian laws and regulations currently in effect by taking into consideration moral standards and not to replace those provisions, will further strengthen the competition for satisfied consumers in the market, and the quality and effectiveness of lending services in the retail segment" (Hungarian Banking Association 2015:1).

The above citations include most keywords related to the subject matter of our analysis: fair conduct, regulatory compliance, self-regulation, moral standards, clarity, and fair market competition. That said, the three principles enshrined in the Code need to be highlighted: transparency, compliance and symmetry. With this also in mind, the banks signing the Code undertook a commitment pursuant to Act XLVII of 2008 on the Prohibition of Unfair Commercial Practices against Consumers, which is peculiar and unique because on those grounds the Code represented a legally binding obligation for the signatory banks. The fact that a code of conduct and ethics is legally binding is clearly attributable to the effect of the crisis. Simultaneously, commercial banks revised their own codes of ethics and internal standards of conduct accordingly. As part of that process, the Hungarian Banking Association also updated its Code of Ethics and the operating procedures of its Ethics Committee.

Measures to enhance trust included the strengthening of the deposit insurance scheme and an increase in the insurance limit. In that regard, Hungary followed the applicable and legally binding directive of the European Union, increasing the deposit insurance limit in accordance with the EU objective that - as part of developing the Banking Union - implementation of the European Deposit Insurance Scheme should occur along with the Single Supervisory Mechanism and the Single Resolution Mechanism.

By the mid-2010s, the operations of the banking sector were back to normal, which could not have been accomplished without sacrifices. State intervention was successful in every country, bringing about over-regulation and major changes in banks' business models, organisation, and arrangements for governance, management and risk management. At the same time, ethical and conduct standards were applied on a large scale. It was in that new 'peacetime' that prominence 
was given to the restatement of ethical standards for banks, and to the process of rebuilding trust in banks. Nevertheless, two questions remain valid. The first is whether the banking sector can again be driven into a situation, similar to that seen before 2008, which Chuck Prince, CEO of a Citibank distressed due to the crisis, explained and described by saying, "as long as the music is playing, you've got to get up and dance." The second concerns how the requirements for ethics and trust are likely to evolve and change in the FinTech world.

\section{Trust, confidence and ethics in the world of digital finance? Harmony and disharmony}

As indicated earlier, general trust in the banking sector had been largely restored by the mid-2010s. Also from the perspective of banking history, during that period a number of new features, changes and challenges emerged in the financial intermediary system. Banks adapted to the international and national regulations and supervisory standards, which had been tightened in response to the crisis and covered the smallest details of their operations. Where they were needed, resolution exercises were completed, allowing banks to meet the new capital requirements. Previously prevented by the crisis, developments were now launched in computing and other fields. Boosted by economic growth, corporate and retail lending grew at an accelerating rate. The favourable situation that emerged saw the revival and increasing intensity of competition among banks. It soon became clear that the operating environment of banks had changed significantly compared to the pre-crisis period. By analogy, the new situation may be described as that of an orchestra which, despite the instruments and most of its members being the same, is compelled to play new music due to changes in concert settings and audience requirements.

In this economic peacetime, the banking sector and the financial intermediary system at large could not avoid digital transformation, considered to be a part of the fourth industrial revolution, which, in some of its elements, was already emerging at the turn of the millennium, but only had a tremendous impact after the financial crisis. These 'revolutionary' changes are setting new requirements for financial services and service providers in terms of trust, confidence and ethics. Regarding the focal theme of our analysis, to use another analogy, we have reached a roundabout, which has the financial intermediary system at its centre, with several roads leading into and out of it. We would like to use this image (see Figure 1) to reinforce and support a number of our conclusions. Foremost, the fact that even the financial intermediary system is at the heart of both digital financial services and the world of the service providers that provide those services. In other words, it is the opportunities inherent in the financial intermediary system operated by incumbent banks that FinTech and BigTech companies are exploiting. The second round of the roundabout illustrates the fact that, apart from 
financial services, FinTech companies today are also taking deposits and lending on an increasing scale. The outer framework of the roundabout shows that the entire process is enclosed by the need for international and national regulation and supervision. This is represented by the international and national regulatory and supervisory authorities shown in the figure, and the regulatory sandboxes ${ }^{6}$ and innovation hubs created and used by them. However, at present, such efforts predominantly rely on the emerging standards of trust, ethics, morals and conduct, on which Figure 1 is based.

\section{Figure 1}

Roundabout of the services of FinTechs and incumbent banks

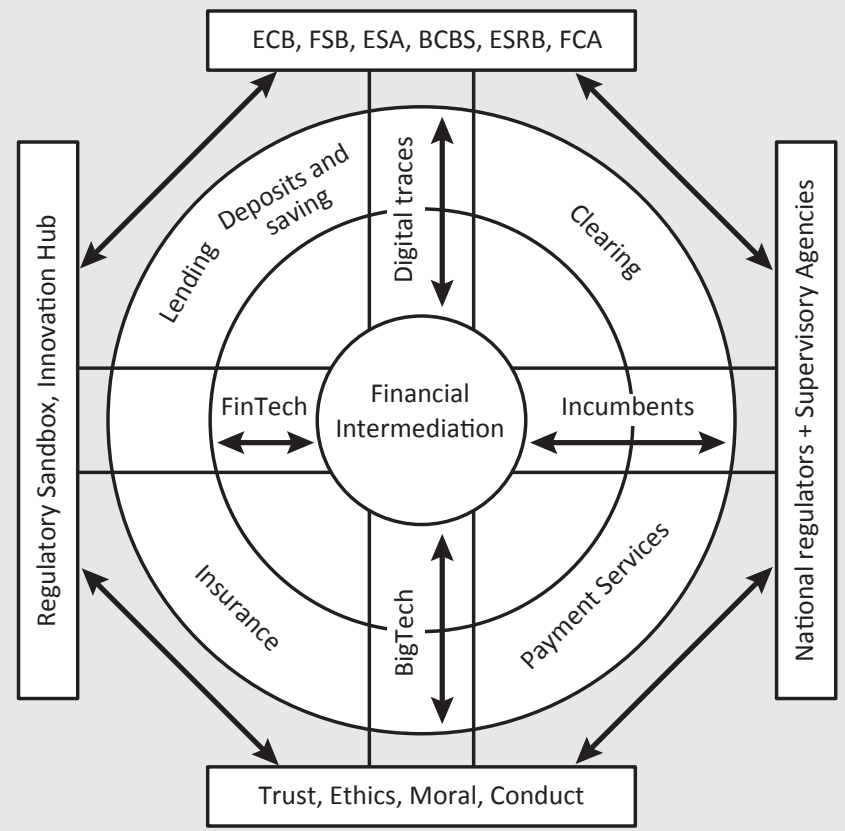

At the junction characterised by this roundabout, new participants have appeared and entered from several directions. Ushered in by the emergence of the digital world, they initially gave way to the incumbents of the financial market. FinTech start-ups took advantage of the lower speed at which incumbent banks were able to launch online digital services in the period of recovery following the crisis. Initially, providers exploding onto the market had the tendency of relying

\footnotetext{
${ }^{6}$ In a Hungarian context, the MNB uses the Hungarian equivalent of 'Innovative Financial Test Environment' (source: https://www.mnb.hu/innovation-hub/regulatory-sandbox and Fáykiss et al. 2018).
} 
on digital and innovative developments to set up profitable businesses with low capital needs and a quick return on investment, exploiting the niche created by the demand for fast and cheap payment services. Digital development was also seen as a matter of global competitiveness by Member States of the European Union, with FinTech start-ups enjoying overall support for their development and market entry on multiple levels. By contrast, incumbent banks were required to comply with the tight regulations applicable to them in order to launch services of this type, while FinTech companies were considered by regulators to be outsiders to the banking sector. This was partly due to the absence of a generally accepted definition of FinTech in technical literature that would be suitable for regulatory purposes. To date, the working definition adopted by the Financial Stability Board (FSB) of the Basel Committee on Banking Supervision (BCBS) is still in general use, according to which FinTech is "technologically enabled financial innovation that could result in new business models, applications, processes, or products with an associated material effect on financial markets and institutions and the provision of financial services". The BCBS considers that the above broad definition can be used pragmatically notwithstanding the changeability that characterises the current development of FinTech.

Obviously, the general support granted in the early stage and the flexible and broad definition had serious consequences, because the latter fails to clearly identify the contents and scope of FinTech services, while making it difficult to establish the legal framework and the confines of supervisory controls, and the provision of a level playing field for incumbent banks and FinTech companies.

In that initial setting, neither regulators nor customers were particularly concerned with the question of trust. No major doubts were raised over trust, only banks protested occasionally against the uneven playing field. What created or led to this situation in which trust was not called into question?

In the beginning, it was sufficient for FinTech companies to reach smaller, 'niche' customer segments to be successful, while the BigTech companies emerging later offered credit and other options to complement their non-financial services. In this changed environment, the ways to build trust were fundamentally influenced by the accelerating and significant transformation in the nature of customer relations. The unique character of the relations of incumbent banks with their corporate and retail customers stems from the emphasis on stability and a long-term perspective, making banks' approach to their customers relationship-oriented (authors' italics), as opposed to FinTech providers' deal-oriented focus on individual transactions. In the latter case, whether it is mobile payments, electronic banking, or online purchases linked to credit, the common feature is that access is made to a service in a fast, convenient, efficient and cheap way. At the same time, access to a digital service only takes a short time, with variations in the place and means of occasional 
access and no stable relationship, and most importantly, without any human or institutional relations. The above distinction in quality was made by the European Banking Federation (EBF), representing the banking community of thirty-one countries, in connection with the level playing field that will be required for banks in the future for the sustainable finance of the economy (EBF 2018:3). In that regard, the emergence of BigTech providers is two-faceted because their repeated or more stable customer relationships are commercial in nature, and such providers build on that to provide occasional financial services.

The digital age is a major challenge both for incumbent banks and for customers. As far as banks are concerned, in order to build or renew their relationship of trust with customers, they have had to prove that they have addressed the negative effects of the recent global financial crisis, that their operations are stable, sustainable and profitable, and that they provide competitive and reliable services to their customers. They have also had to prove that in the foreseeable future they would provide all of the services that FinTech companies had to offer. They must (should) make customers realise that they benefit from a stable banking relationship.

We have already suggested that the balance of trust and mistrust could give rise to a situation on which stakeholders can build. "If the lifeblood of the digital economy is data, its heart is digital trust - the level of confidence in people, processes, and technology to build a secure digital world. Companies, regulators and consumers need fresh mechanisms to build confidence as they address emerging challenges in business, risk management, and compliance" (Fleming 2018:1). We have come to an important issue, the problem of a surplus and deficit in trust as regards the relations of incumbent banks and FinTech providers. Experience shows that while the younger generation prefers FinTech solutions, has advanced digital and internet skills and believes in fast and cheap payment solutions, their financial awareness is not always on par with their ability. Given this disproportionate situation and this customer segment, a major change is taking place in the way incumbent banks create balance, and gain and build trust.

\section{Building the digital financial architecture - Where do we stand?}

One common feature of revolutionary changes is that they are extremely fast and often disrupt the established traditional order. Central banks, regulators and supervisors are working to keep abreast of the rapid changes in digital development. While their approach to FinTech is essentially supportive (as shown e.g. by Regulatory Sandboxes and FinTech hubs), the first warning signs are starting to appear. Authorities and studies have increasingly been proposing that services of this kind should be regulated, ethical requirements should be set, and consumer confidence and security should be enhanced. 
Events indicating that unregulated or loosely regulated trends in FinTech could involve risks intensified starting from 2016-2017, underlining the need for both regulation and international cooperation. Despite the increased prominence of the need for equality in services and regulation, and for a level playing field, no significant progress has been made in that regard.

In 2016, the Financial Stability Board, the highest-level international regulatory body, began to address the regulatory and supervisory aspects of the FinTech phenomenon in greater depth, and in 2017 it already raised possible issues with financial stability when it reported that potential risks included institution-specific micro-financial risks, which may evolve into systemic macro-financial and prudential risks, partly due to the high degree to which data are interconnected. Driven by those conclusions, the FSB is now closely monitoring the stability implications of FinTech trends.

An FSB report from early 2019 already points out that FinTech services can and do have an impact on market structure and financial stability. In its analysis, the Board examined three types of FinTech presence in the market (FSB 2019):

1. They may partner with (or be taken over by) financial institutions, allowing the institutions to improve their service level or efficiency.

2. They may provide a service which is complementary to those provided by existing financial institutions. This could improve the attractiveness of the existing service, e.g. payments 'front-ends' that utilise existing networks and maintain (or increase) existing transaction flows. While these services may complement those offered by a financial institution, they may have some detrimental effects on the financial institution, by replacing or weakening the institution's traditional customer relationship.

3. They may compete directly with existing financial institutions, reducing margins in the affected segments and reducing the financial institution's capacity to crosssubsidise products.

Based on an in-depth analysis of these three aspects, the FSB concludes that the risks identified may become more acute for three reasons: (a) the raft of new technologies introduced in the past few years, and the impetus provided by open banking could also quickly change the dynamics of competition; (b) changes in business models may occur more quickly than in the past as BigTech companies actively and successfully push into traditional financial services; and (c) the technology focus of both new providers and incumbents - particularly where they are closely integrated into firms' operations - may entail a new dimension of operational risks. 
The FSB draws regulators' attention to new types of risk and the potential detriment to financial stability. "The potential macro-financial risks from these developments relate to the effects of competition and disruption of business models on profitability, and therefore the ability to accumulate capital through retained earnings. This largely arises where FinTech firms actively compete with the incumbents or where their actions increase the mobility of customers. This could ultimately lead to an inappropriate loosening of lending standards by banks, and more risk-taking by other financial institutions" (FSB 2019:16). The FSB considers that "BigTech firms may provide various free services because of their ability to use the data for other business lines. Customers provide personal data in exchange for using these services, instead of paying fees" (FSB 2019:19).

Of course, reducing or eliminating potential risks may directly influence the trust in financial service providers, whether that trust is being built or undermined. In this context, in addition to the need for regulation, the FSB places strong emphasis on the need to determine from the outset the conditions for licensing the activities of FinTech providers.

On the subject of regulation and licensing, we refer to the European Central Bank's publication of its Guide to assessments of FinTech licence applications, and its Guide to assessments of FinTech credit institution licence applications (ECB 2018). According to the Guide, the general criteria assessed in the licensing process include, but are not limited to, the following four areas: (a) governance (suitability of the members of the management body and suitability of shareholders); (b) internal organisation (risk management, compliance and audit frameworks); (c) programme of operations; and (d) capital, liquidity and solvency.

As we have seen, both the FSB and the ECB place emphasis on the licensing and regulation of digital financial services and on related international cooperation, while being compelled to keep regulation itself, i.e. the solutions to the problems, within the sphere of national competence.

While warning signs are multiplying, understanding the delay in comprehensive regulation requires an overview of the essential tools and background of digital financial services, i.e. the use of big data, reliance on customers' digital traces, artificial intelligence (AI) to assist data utilisation, the methods of machine data analysis (big data and $\mathrm{API}^{7}$ ), and robotics. Indeed, it is from this side that the darkest shadows are cast on FinTech, which is why the need for trust and ethics is also strongest here. Researchers at the University of Hong Kong described this as follows: "FinTech today is often seen as a uniquely recent marriage of financial services and information technology" (Arner et al. 2015:3).

\footnotetext{
${ }^{7}$ Application Programming Interface
} 
Apart from the rapid development of digital technology, the difficulty of regulation lies in this complex formula. This is because while regulators strive to regulate the financial services that are offered and provided, the tools of these services (such as big data and $\mathrm{Al}$ ) are difficult to identify and regulate. As a prominent example, FinTech companies use large amounts of data to provide their services. Some of that data is provided by willing and knowing customers, while in other cases customers understand little about what they are consenting to, or the source of their data. A large part of the latter is referred to as digital trace data. Describing the nature of such data, a Swedish researcher refers to the international controversy over who owns and holds the data collected and used digitally (Bogusz 2019:1). With incumbent banks, the answer to that question was clear: the data could only have two owners, the customer and the bank. Such data were strictly protected by bank secrecy. Without that, no trust or business relationship could have existed between a bank and its customer. "The long-term sustainability of business models based on digital trace data requires that firms consider both privacy concerns and quality concerns when building their services. Given the potentially invasive nature of data collection, and the implications of possible backlash, FinTech firms need to be careful when designing [...] their services. There must be clear rules for present and future FinTech companies about the protection of personal data and the ways in which they can be processed, and it is inevitable that the moral and ethical aspects of this issue be taken into account" (Bogusz 2019). This principal requirement is also supported by FinTech providers' extensive use of Artificial Intelligence in areas such as rating credit applications, direct lending, portfolio optimisation, risk analysis of insurance assets, or the investigation of suspected fraud and regulatory compliance.

The massive volumes of data, which are occasionally obtained by invasive means, support the rapid spread of FinTech in a variety of forms. Facebook has recently applied for licences to take up banking operations, while Robinhood, one of the world's first free securities trading companies, has also applied for a banking license of its own. The question arises why such companies are going down that avenue in business. The answer is simple: they have accumulated vast amounts of data, and by granting access to the data of bank clients, the PSD2 ${ }^{8}$ has opened the door to payment services wide in front of them, virtually setting off an avalanche.

Thanks to Facebook, this entire strand of digital development has recently taken new and unexpected turns. Following a series of criticisms concerning the ways Facebook was using and processing data, in spring 2019 Mark Zuckerberg, founder and CEO of the community site, published an open letter in The Washington Post, asking governments to impose legal regulations and controls on the Internet. A few months later, Facebook agreed to pay a USD 5 billion fine at the end of an investigation into the Cambridge Analytica scandal. In the course of the proceedings,

\footnotetext{
${ }^{8}$ Revised Payment Services, Directive (EU) 2015/2366
} 
the results of which included a loss of confidence, Mark Zuckerberg also appeared at a U.S. Senate hearing to announce and promise a number of measures concerning ethics and trust enhancement. "Now, Facebook might not intend to be dangerous - but they certainly don't respect the power of the technologies they are playing with. Like a toddler who has gotten his hands on a book of matches, Facebook has burned down the house over and over, and called every arson a learning experience. Facebook has two competing missions - make the world more open and connected, and make a lot of money. And as Facebook attempts to serve both of those missions, they wreak havoc on the rest of us" (Brown 2019:1).

Another turning point was the announcement of Facebook's own cryptocurrency Libra, which raised concerns in both the U.S. Fed and the ECB. This series of Facebook events is worth mentioning because it highlights the delicate nature of data that is acquired and stored digitally and used in versatile ways, provokes a regulatory response (in retrospect, without any significant results), and shows that the massive amount of data at hand even creates a theoretical possibility for issuing a cryptocurrency that could hardly be controlled in monetary terms.

Returning to the above argument initiated by PSD2, it should be recalled that the Directive enables FinTech companies to initiate online transfers on behalf of users, and forward the related instructions to banks, or provide other services such as lending. FinTechs can thus carry out in-depth analyses of an individual's spending behaviour. The new options include Account Information System Providers (AISP) and Payment Initiation Service Providers (PISP).

Apparently, the dual role of regulators is further strengthened. Regulatory support is growing, but new entrants represent such a wide range of financial services that statutory regulation can only try to catch up. Due to the concerns expressed by both the FSB and the ECB in very clear terms, additional requirements have recently become increasingly important, given the inadequate or non-existent effects of statutory regulation. These include, for example, developing, applying, and requiring the duty of care, and conduct and ethical standards to build trust. We are providing an overview of these developments as indications of a paradigm shift.

A precursor to the need for regulation is the Global Financial Innovation Network (GFIN) initiative, which has created a cross-border regulatory sandbox to test innovative financial products and services. GFIN Chair Andrew Bailey, Chief Executive of the UK's Financial Conduct Authority (FCA), announced the organisation's plans to unite regulatory bodies from 29 countries, and that applications for testing have already been received from some 50 FinTech companies. In this situation, the FCA has sought to build a bridge of international use between the need for regulation and the promotion of fair FinTech conduct: "I support successful open financial markets, with free trade that points away from tying markets to locations, and 
markets that are global not narrowly regional. But, the big but, all of this needs to be done on a basis that is fair and sustainable, and fair to all groups in society reflecting the different capacities and vulnerabilities that exist in any society including our own. The public interest demands that we combine success with fairness and sustainability" (Bailey 2019:1).

In that context, the principle of the duty of care is introduced, the application of which requires FinTech companies to assess their operations by asking whether those operations were 'right' rather than by asking whether they 'complied with the rules'. The authority would set out clearly the expectations and/or claims consumers may have in their relations with FinTech companies, and would develop a consistent and comprehensive concept of care to help restore consumer confidence. In this sense, the duty of care is essentially a form of conduct that is instrumental in developing the novel codes of conduct for banks and FinTechs. In short, the initiative reflects the realisation that services of this type need to be regulated, but does not go beyond the formulation of standards of care that build trust. As we have seen, there is an acute need for international cooperation in the field of regulation. A good example of how to initiate and build this has been provided by Austria, whose Minister of Finance has announced the development of a regulatory sandbox in close cooperation with the FCA, which represents a further step towards a single international approach. "The FinTech Advisory Council, created last year, will help create the relevant rules to govern the young financial market around digitised financial services. The management of the Regulatory Sandbox will ensure the necessary supervisory oversight while at the same time encouraging innovation and growth" (Loeger 2019:1).

In a similar vein, the Magyar Nemzeti Bank has a close professional relationship with the FCA, and has also joined the GFIN network. "This network seeks to facilitate international cooperation between authorities and innovative market operators, and to provide joint support for the global roll-out of FinTech solutions. The international network provides a framework for countries for the formalised and effective exchange of information and experience on FinTech innovations, as well as on RegTech developments, the innovative solutions specifically used to meet regulatory requirements" (MNB 2019:1).

One of the voices in the 'choir' is that of European Supervisory Authorities (ESAs), which are important means of harmonised EU regulation. "Financial Technology (FinTech) is transforming financial services. It facilitates access to financial services and makes them more convenient. It increases operational efficiency and can lower costs for consumers. It may also lower barriers for new market players and increase competition. For these benefits to happen, it is important to ensure the integrity and resilience of IT systems, data protection, and fair and transparent 
markets. [...] This will require them to enhance a common EU supervisory culture as regards technological innovation among competent authorities. In particular, the ESAs has been tasked with coordinating national technological innovation instruments and tools - such as innovation hubs or 'sandboxes' - set up by national supervisors. Furthermore, the ESAs will promote technology literacy with all national supervisors alongside information sharing on cyber threats, incidents and attacks" (ESA 2019:1-2).

Here we have another important guidance, which, however, in practical terms, does not achieve more than setting the requirement for competent authorities to enhance a common EU supervisory culture as regards technological innovation in financial markets.

\section{The grounds and architecture of trust in the FinTech world: the relationship between regulation and ethics}

Above we have given an overview of the role of trust and ethics in our 'modern age', as they emerged over time for incumbent banks and FinTech providers. The international and the Hungarian banking system are both undergoing a period when digital development is spawning new challenges for all participants in the financial and banking system. For a decade now since the last financial crisis, economic conditions have allowed the undisturbed development of financing for sustainable economic growth, and the banking market has experienced a revival of healthy competition. It was in this almost idyllic setting that we saw the emergence of the difficult, or perhaps novel, questions formulated at the outset of this paper. We examined the operating environment and regulation of the financial intermediary system, as well as the related issues of trust and ethics primarily in the context of EU and domestic relations, from the perspective of a Member State of the European Union. The post-2008 period saw the development of a whole regulatory arsenal and an institutional architecture to strengthen the secure operations of the banking sector across the European Union. Significant progress was made in building the Economic and Monetary Union, the Banking Union and the Capital Markets Union. The emerging regulatory system was more nuanced, more consistent and supported greater security in the functioning of the banking system.

At that time, however, participants driving development in digital finance entered the market: the first of these were FinTech companies, followed shortly by BigTech, and even third-party providers (TPP). As a result of their steadily growing market presence, central banks, supervisors, regulators, and incumbent banks themselves were facing decisions. 
International and national regulators were giving increasingly firm indications that FinTech developments carried risks to financial markets, and involved effects that were disruptive for the financial intermediary system. They called for comprehensive international and national regulation that would create a level playing field between incumbent banks and FinTech/BigTech companies, while also reducing risks. They found themselves faced with the need to establish prudential rules as well as rules concerning systemic risk and consumer and data protection in a complex situation where even a precise definition was lacking for the subject matter of regulation. All of this occurred in an environment where the majority of digital financial services were provided across borders, which required decisions as to what would be regulated by who and where. Against this backdrop, the European Central Bank has taken the position that for the time being FinTech services should be managed and regulated within the scope of national competence. In order for regulators to get up to speed with the trends, workarounds need to be found to temporarily substitute for regulation.

As a first step, the need to support the market entry of FinTech companies gained acceptance, leading to the set-up of incubators and regulatory sandboxes. These were expected to produce two effects: first, to introduce start-ups to the requirements for regulated operations with which they had to comply, and second, to provide insights into and an understanding of their services, based on which rules could be developed.

In the period without statutory rules, the next stage was marked by the formulation of ethical and conduct standards and duties for care, the need to enforce these, and the hope that the foundations of building trust could also be laid. This is a field where incumbent banks had and continue to have traditions and experience. While the process was accelerated by the rapid development and market penetration of digital financial services, from the outset the fundamental question in this regard was: if ethics, whose ethics? This question could not have been raised with regard to the codes of ethics of incumbent banks, since the requirements for ethics and fair conduct applied to the services of the given financial institution, the employees producing and providing them, and even to management. As we have seen, such codes helped to enhance trust, demonstrating banks' compliance with the rules as well as their ethical business conduct.

The world of FinTech is governed by a different formula and structure for ethics. The first essential difference lies in the aspect of time, because, as we have seen, in the case of incumbent banks it was in the aftermath of individual shocks that ethical standards gained prominence in order to restore trust. Most users have positive perceptions of FinTech-type financial services, and say that such services are fast and cheap. Those users have no suspicions and are not sensitive to risk. 
However, complaints and critical comments are increasingly targeted at phishing, i.e. the collection and use of personal data, in particular digital trace data, in ways that are not known to data owners. As a result, we are faced with a situation where the standards of ethics, conduct, behaviour and care would primarily be supposed to substitute for delayed statutory rules. The rules for FinTech ethics emerge in an undisturbed economic and financial environment. Another feature distinguishing them from incumbent ethics is that such rules do not or not only apply to the end result of the service provided, such as payment services. As mentioned earlier, both the FSB and the ECB consider it important to impose statutory licensing requirements on the launch of FinTech operations, which is right, but makes it readily apparent that such licences will be limited in their ability to address the massive volume of data and the use of artificial intelligence underlying those operations.

Accordingly, due to the existing but insufficient regulation, efforts are being made to introduce application standards, akin to ethical norms and guidelines in character, in order to 'regulate' the toolkit of FinTech/BigTech financial services, i.e. the use of artificial intelligence, big data and digital traces.

There are many examples of the pursuit of statutory regulation in various countries. One is the United States. In consideration of the potential risks and invoking the position taken by the Board of Governors of the Federal Reserve System, Democrats passed a bill in the U.S. Senate's Financial Services Committee under which BigTech companies using large platforms would be forbidden from creating, maintaining and operating a digital device or program that is widely used as a means of exchange, unit of account, store of value, or in other similar functions.

Recognising and highlighting the risks to the financial intermediary system and to financial markets, a process has started for the development of a framework on ethics and care. As an integral part of that process, the standards to be introduced were extended to the tools used by FinTech companies. In April 2019, the European Commission published a document entitled 'Ethics Guidelines for Trustworthy Artificial Intelligence' (European Commission 2019a). According to the Guidelines, "Al systems need to be human-centric, resting on a commitment to their use in the service of humanity and the common good, with the goal of improving human welfare and freedom. While offering great opportunities, Al systems also give rise to certain risks that must be handled appropriately and proportionately. We now have an important window of opportunity to shape their development. We want to ensure that we can trust the sociotechnical environments in which they are embedded. We also want producers of Al systems to get a competitive advantage by embedding Trustworthy $A l$ in their products and services. This entails seeking to maximise the benefits of Al systems while at the same time preventing and minimising their 
risks. In a context of rapid technological change, we believe it is essential that trust remains the bedrock of societies, communities, economies and sustainable development. We therefore identify Trustworthy Al as our foundational ambition, since human beings and communities will only be able to have confidence in the technology's development and its applications when a clear and comprehensive framework for achieving its trustworthiness is in place" (European Commission 2019a:1-2).

The Commission's document sets out the requirements for ethical artificial intelligence: "Achieving Trustworthy Al requires not only compliance with the law, which is but one of its three components. Laws are not always up to speed with technological developments, can at times be out of step with ethical norms or may simply not be well suited to addressing certain issues. For Al systems to be trustworthy, they should hence also be ethical, ensuring alignment with ethical norms. It is only with trust that our society can fully benefit from technologies. Ethical $\mathrm{Al}$ is a win-win proposition that can become a competitive advantage for Europe: being a leader of human-centric Al that people can trust" (European Commission 2019a:3).

In defining the essential requirements for trustworthy, ethical, human-centric Al, the Commission proposes a multi-step approach. Under that approach, trustworthy Al must respect all laws and regulations. The assessment lists used for this purpose are designed to help identify and control the application of key requirements such as human agency and oversight; safety; privacy and data governance; transparency; environmental and societal well-being; and accountability. Trustworthy Al systems cannot function unless there is international consensus on human-centric Al. The European Commission would welcome the global enforcement of the approach to Al ethics on the grounds that technologies, data and algorithms do not stop at borders. To this end, the Commission will strengthen its cooperation with partners of a similar mindset, such as Canada and Japan. This objective of the European Commission represents a milestone, and a breakthrough in a sense.

Apart from competent authorities, scientific research has also been addressing ethical premises. In 2017, the Oxford Internet Institute set up a unit called the Digital Ethics Lab ('DELab') to tackle the ethical challenges posed by digital innovation as they permeate technology, science, law, business, and not least society as a whole. "The DELab aims to identify the benefits and enhance the positive opportunities of digital innovation as a force for good and avoid or mitigate its risks and shortcomings," said Luciano Floridi, the OII's Professor of Philosophy and Ethics of Information. Supported by a donation of approximately USD 190 million from the U.S.-based Blackstone fund, Oxford's new Institute for Ethics in Al was founded in 2019 as a research centre specifically dedicated to the study of ethical 
aspects in artificial intelligence. Upon its foundation, emphasis was given to the importance of research into Al ethics on the grounds that the governments of the world were not prepared to address the effects of artificial intelligence, which calls for an understanding of identified standards of ethics and conduct in efforts to regulate those effects.

As the activity of smart and intelligent machines based on $\mathrm{Al}$ is an important element in the implementation of FinTech services, many researchers have addressed the ethical requirements, including the lack of the necessary regulatory framework. The following are highlights from the assertions of two noted researchers: "Artificial intelligence (AI) relies on big data and machine learning for myriad applications. The availability of large amounts of data is essential to the development of Al. But the recent scandal over the use of personal and social data by Facebook and Cambridge Analytica has brought ethical considerations to the fore. And it's just the beginning. [...] How do we bring more awareness about such responsibility, in the absence of a global standard on Al? The ethical standards for assessing Al and its associated technologies are still in their infancy. [...] Given the stakes and the thirst for data that Al involves, it will likely require companies to ask very tough questions as to every detail of what they do to get ahead. The way industry and society addresses these issues will be crucial to the adoption of Al in the digital world. However, for Al to deliver on its promise, it will require predictability and trust. These two are interrelated. Predictable treatment of the complex issues that Al throws up, such as accountability and permitted uses of data, will encourage investment in and use of Al. Similarly, progress with Al requires consumers to trust the technology, its impact on them, and how it uses their data. Predictable and transparent treatment facilitates this trust" (Guillén - Reddy 2018:1-2).

There have recently been many allegations that businesses have not used Al ethically. Presumably, this criticism was not unfounded because Amazon, Google, Facebook, IBM and Microsoft have formed a non-profit partnership to establish best practices in artificial intelligence technologies and promote public understanding. This example is highlighted here because the five global users have come to the conclusion that in the absence of regulation, they were supposed to develop a proprietary data processing platform that was self-regulatory in character, and enhanced trust.

The above overview affords a comparison between the developments in the standards of trust and ethics for incumbent banks and FinTech type financial service providers. What emerges from that comparison is an evolutionary process that can be figuratively represented by an hourglass. We see a complete reversal in the order and weights of regulation and of ethical, moral and behavioural requirements for incumbents and FinTech/BigTech companies. In the case of incumbent banks 
in general, and with a compulsory character in the wake of the most recent international financial crisis, regulations as well as loss and risk mitigation measures were introduced on a massive scale. Once we are past most of the recovery from the destruction caused by the crisis, it becomes timely and necessary to build trust, and foremost, to regain customer confidence. One common element in those efforts is to rethink and declare ethical and conduct standards. These codes of ethics are not substitutes for regulation, but are built on and reinforce it (a unique exception is the Hungarian Code of Ethics of 2015, referred to previously, which was legally binding at the time). The process is described by the upper part of the hourglass representation.

The consequences of FinTech's market penetration are illustrated by the lower part of the hourglass. When digital financial service providers first started to emerge, users of their services were satisfied, responding positively to speed, online administration and lower costs. Providers were trusted by customers, which is perhaps more aptly described as the absence of a deficit in trust.

For the reasons explained above (extremely rapid penetration, developments detrimental to the regular operation of the financial intermediary system, anomalies in the acquisition and use of data, absent and delayed regulation), certain risks in digital financial services became evident, and efforts to contain those risks were made by means of codes of ethics, conduct, care and self-regulation. Over time, the requirement for regulation becomes increasingly strong. This stage of development is represented by the lower part of the hourglass (Figure 2). 
Figure 2

Hourglass: bank and FinTech ethics over time

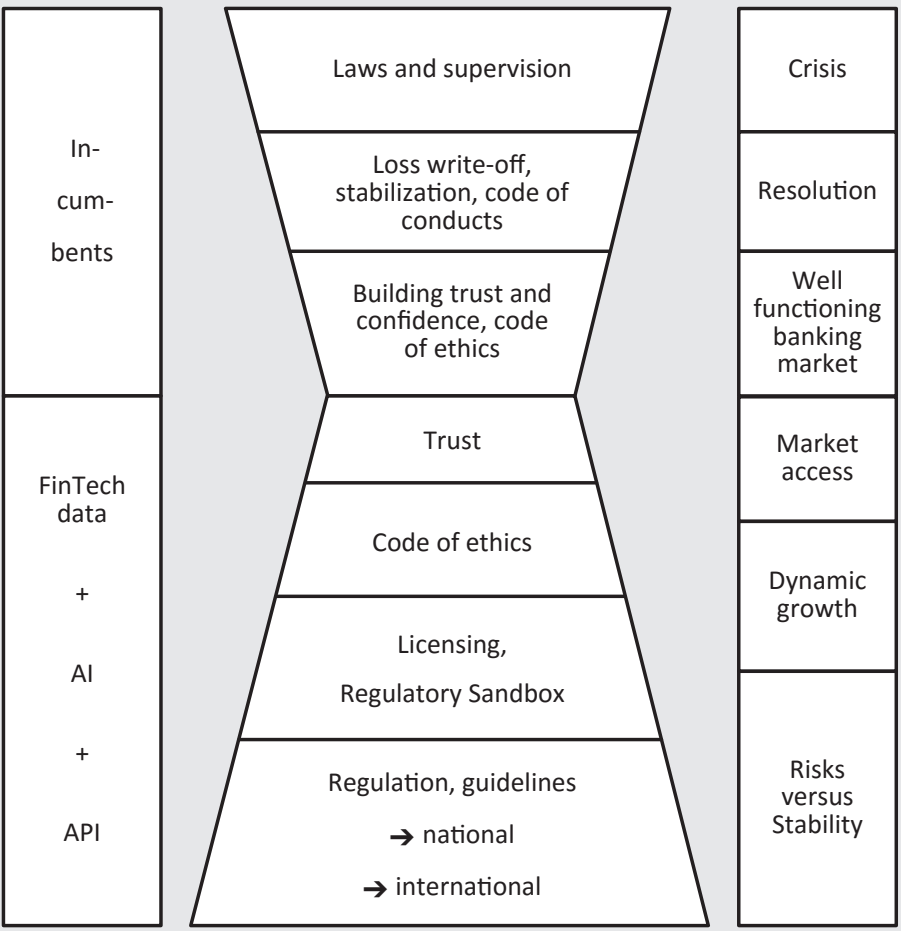

Naturally, FinTech's current ethical requirements include the buzzwords of the codes of ethics for incumbents, such as fair business conduct, transparency, the duty of care and regulatory compliance. However, there are two differences. On the one hand, in the case of incumbent banks, ethical standards focus on the realised and 'sold' banking product (such as lending) and the related business conduct, and the internal parts of the codes provide guidance on the ethical conduct of bank employees. By contrast, FinTech ethics in respect of services enhance the careful realisation of transaction-based activities. However, in the realisation of the service the focus shifts from the human aspect to artificial intelligence and robotics. Responding to problems with the ways in which data were used and processed, the requirement emerged for specific standards of Al ethics in respect of the artificial intelligence applied. The peculiarity and novelty in such ethics is the prohibition of harm to humans, the requirement of being human-centric, and the prohibition of robotics turning against humans. For example, responsibility for decision-making is examined within that framework. In particular, how can the responsibility for decisions be shared when using Al, and who will be liable for risk in the event 
of errors causing damage? From another perspective, where complex machine learning systems are used to make important decisions, the drivers behind the series of actions concerned can only be explored if the principle of transparency is applied. In connection with data protection and internet security, the great power of Al that is rooted in access to big data is also under scrutiny from an ethical point of view. What happens if an Al system is trained on a data set and then applied to learn a new data set? According to the ethics guidelines, responsible Al provides for the moral principles and values to prevent any breach of basic human ethics.

Regarding FinTech and other digital-based financial services, the European Commission reiterated the need to reduce potential risks and strengthen the network of trust that supports such services. The European Commission has published its guidelines on the use of artificial intelligence, asserting that "...the ethical dimension of $\mathrm{Al}$ is not a luxury feature or an add-on: it needs to be an integral part of Al development" (European Commission 2019b:1). In defining the essential requirements for trustworthy, ethical, human-centric $\mathrm{Al}$, the Commission takes a multi-step approach.

\section{Sunshine and shadows, sunshine or shadows? Summary}

Since the emergence of digital financial services as part of the fourth industrial revolution, and the rapid increase in their market share and user numbers, the consequences of their activities have been analysed by all stakeholders, including the FinTech companies themselves. Innovative services were greeted with cheers because they were fast and cheap, and users had not the slightest distrust rooted in potential risk. The launch of such services enjoyed support from both economic policy makers and supervisors, who argued that rapid digital development was essential for keeping up with international competition. Initially, incumbent banks did not consider FinTech start-ups to be a serious challenge, resting assured that needs be, they would either implement similar developments or merge the best start-ups. FinTech companies were also delighted by the ability to create fastgrowing and profitable businesses by carrying out developments of intellectual value with low capital needs and without excessive regulatory restrictions. Arguably, this was the bright golden age of FinTech development.

Rapid and diversified development, and the entry of new types of actors gave rise to and foreshadowed problems that needed to be identified, and for which solutions had to be found. In 2019, the FSB went as far as to state that FinTech developments could disrupt the financial structure and pose a threat to financial stability, while the European Central Bank has stressed the need for a level playing field, and for equality in services and regulation. 
The analysis of these initial conditions and rapid developments showed that the supervision and regulation of a given financial service and service provider was no longer sufficient and should be extended to the tools of underlying the service, such as artificial intelligence. As comprehensive and harmonised regulation has yet to be developed, requirements for ethics and self-regulation have been introduced as substitutes.

To draw lessons and conclusions, we abstracted the requirement for trust, confidence and ethics as a traditional value underlying the successful operation of incumbent banks. We then reviewed the regulatory situation and needs as far as developments in digital finance were concerned.

We described the process under review in stages. Following the international financial crisis, incumbent banks had to restore their operations and consolidate their trust and ethics capital. Offering digital financial services, FinTech start-ups emerged as challengers. They were met with consumer trust, while their market weight was considered marginal and risk-free by banks and regulators. In the second half of the last decade, FinTech spread at a revolutionary pace, giving rise to three types of threat. Incumbent banks indicated that regulation did not provide for a level playing field and that PSD2 amendments would expose them to major losses in data and markets unless they implemented digital developments at significant cost. International regulators issued warnings indicating rapid changes in market structure, financial stability issues and competitive constraints that posed microand macro-financial risks. To address potential problems relating to financial stability, the need to regulate FinTech emerged at the national and international levels. A survey of the means required revealed that it was not enough to regulate FinTech providers and products alone. Potential risks are carried by the amount of data used, artificial intelligence, and the algorithms processing big data.

As comprehensive regulation was not achieved, workarounds such as licensing guidelines were introduced. In the absence of regulation, the need to build trust is evident, which is why the emergence of codes of conduct, ethical standards, duty of care and international regulatory sandboxes was a real breakthrough.

In the mid-2010s, the banking sector overcame the worst damage caused by the financial crisis and sustainable financing for the economy recovered. The need to bring banking over-regulation due to the crisis to a normal level was put on the agenda, and rebuilding trust in the banking system became a central concern. An important building block in the process was the rethinking of banks' ethical standards and codes of conduct. 
During this undisturbed and peaceful period of development, the fourth industrial revolution accelerated, with all its essential elements entering the global economy, from artificial intelligence to robotics. For a long time, incumbent banks looked at new FinTech players without substantive criticism or opposition, and were confident that the new entrants would not be able to take over their core banking services and would remain marginal, or that cooperation or merger agreements would be made with the owners of successful innovations. In the first phase of the process, incumbents mainly protested against the unequal terms, i.e. the fact that regulatory conditions created an operating environment that favoured FinTech companies, and that the playing field was not level. Concerns over risk or issues of trust were not raised either by regulators or by users of digital financial services. Summarising the characteristics of this development phase, the segment of FinTech start-ups can be said to have expanded in brilliant sunlight, driven by regulatory support and market demand.

Of course, the brighter the sunlight, the more pronounced the shadows are. The appearance of several factors within a short period of time indicated that risks are present or anticipated, and that darkness would grow wider and deeper. The approach was adopted that it was better to support FinTech start-ups and get to know them better, and to follow up on developments through regulation. There were various means of support, ranging from regulatory sandboxes to innovation hubs, until PSD2 amendments allowed FinTech companies to access some of banks' customer data.

At this point we reached a milestone. Digital financial services carved out a significant portion of the market and profits of incumbent banks. At the same time, BigTech companies entered the market, offering not only payment services, but also credit, deposit and insurance products, with fast execution and extremely low cost. Giant companies like Facebook applied for and obtained a bank license. According to an official announcement by TechCrunch, Facebook Payments International LTD (FBPIL) was licensed as an electronic money institution as of 24 October 2016 by the Central Bank of Ireland (CBI), enabling to carry out electronic money transfers, payment services and credit transfers.

These digital financial service providers make use of all available elements of digital technology, including big data, artificial intelligence, API data analytics, robotics and the use of digital traces.

When incumbent banks realised that they were out of step, they undertook significant digital developments from 2017, accelerating their digital convergence and requesting authorities to provide a level playing field. 
The next development stage was related to the use of tools and data for digital financial services. There was increasing professional criticism about access to and the use of big data and digital traces. A significant part of that data was collected by algorithms and programmed applications without the knowledge of the owner, but the use of the data subsequently caused problems even if they were recorded with the customer's consent. BigTech companies provide some of their services in exchange for data.

The shadows on FinTech services being darker, it is time for regulators and supervisors to take action. The potential risks were first pointed out by the FSB, noting that the market penetration of FinTech/BigTech companies was changing the structure of the money market and that financial stability risks might arise, and that BigTech services which were fast and were low-priced or free would force incumbent banks to compete, giving rise to operational risks. Due to the potential risks identified, there was consensus among national and international regulators that providers of financial services and FinTech companies should be subject to licensing requirements. In this respect, the European Central Bank issued a licensing guide, but licensing and supervision remained a national competence, while there is a need for harmonised international regulation.

As it is clear that such a comprehensive set of rules can only be expected in the distant future, a set of requirements appeared on the horizon, supported by international agreement and cooperation. This involves the demand for trust and ethics, new behaviours and new standards for the duty of care in the world of FinTech and the digital devices that support it.

In the case of incumbent banks, experience has shown that in the aftermath of individual crises and shocks ethical standards gain prominence, when trust is being restored after regulatory measures for crisis recovery. Initially, as far as FinTech was concerned, the need to build trust was not particularly pronounced, and regulation was loose and accommodating. For example, the primary purpose of regulatory sandboxes was to help FinTech start-ups enter the market. In such an environment, the approved start-ups are temporarily exempted from certain regulations in respect of a limited number of customers for a limited period (e.g. 6 to 12 months). Subsequently, the innovator will be required to comply with all applicable regulations in force.

Rapid development showed that it was not sufficient if the regulation, and the requirement of fair and ethical conduct was applied only directly to FinTech providers and of digital financial services, but the scope of regulation and requirement should inevitably be extended to the tools essential to the business of such providers, including artificial intelligence and the processing of big data. In that 
situation, the application of ethical standards and codes became a matter of primary importance. When regulators finally addressed the requirements of FinTech ethics, the traditional sequence of actions was changed and this was made possible by the fact that the digital financial services described above penetrated the market during a period of sustained, undisturbed economic development. The ethical and conduct standards currently in place and the lack of comprehensive international regulation will be tested when an economic slowdown or recession occurs. That is when the development and tightening of the rules for FinTech is expected to accelerate and become inevitable, and that is when a level playing field with incumbents may be enforced. Based on our experience of digital developments in recent years, we can say that they are capable of mobilising tremendous forces and may have a huge influence on the development and structure of the financial markets.

In this paper, we discussed one of the key drivers of the fourth industrial revolution. The key drivers of the third industrial revolution were machines and the mechanics underlying them. It gives a moral lesson to revisit the statement of the basic law of mechanics at the time: "Mechanics is the science of the effects of forces. The effect of forces is manifested in provoking and preventing the movements of bodies, and in causing or preventing changes to ongoing movements" (Ritter 1879: 1.). Although the 19th-century laws of mechanics did not have a code of ethics, their values can be translated into the language of FinTech and Al.

A final thought: the development of ethical standards in the world of FinTech and BigTech should not be underestimated. Our paper seeks to support the argument for the importance of their role, on the grounds that such standards pave the way for control and accountability, that they provide a conceptual basis for the necessary supervisory and regulatory tasks, and that in a later stage of the process, a harmonious relationship can be established between the ethical values of incumbent banks and those of FinTech providers.

\section{References}

Arner, D.W. - Barberis, J.N. - Buckley, R.P. (2015): The Evolution of Fintech: A New Post-Crisis Paradigm. Research Working Paper No. 2015/047, University of Hong Kong, Faculty of Law. https://doi.org/10.2139/ssrn.2676553

Bailey, A. (2019): The future of financial conduct regulation. Bloomberg, London, 23 April. https://www.fca.org.uk/news/speeches/future-financial-conduct-regulation. Downloaded: 22 May 2019.

Bogusz, C.I. (2019): Digital traces, ethics and insight. Data-driven services in FinTech. In: Teigland, R. - Siri, S. - Larsson, A. - Puertas, A.M. - Bogusz, C.I. (eds.): The Rise and Development of FinTech, Chapter 11. https://doi.org/10.4324/9781351183628-12 
Brown, S. (2019): Facebook is dangerous. Senate Hearing on Facebook Digital Currency Ranking Member Brown Opening Statement, 16 July. https://www.brown.senate.gov/ newsroom/press/release/brown-opening-statement-at-facebook-hearing

Busch, R. (2018): How can we build trust in the digital age? World Economic Forum. https:// www.weforum.org/agenda/2018/01/trust-digital-age-cybersecurity-roland-busch/. Downloaded: 22 May 2019.

ECB (2018): Guide to assessments of fintech credit institution licence applications. Banking Supervision, European Central Bank. https://www.bankingsupervision.europa.eu/ecb/pub/ pdf/ssm.201803_guide_assessment_fintech_credit_inst_licensing.en.pdf. Downloaded: 22 May 2019.

ESA (2019): European Supervisory Authorities: How will the ESA promote FinTech? Brussels, 1 April.

European Commission (2019a): Ethics Guidelines for Trustworthy Artificial Intelligence. European, 8 April, 2019. https://ec.europa.eu/digital-single-market/en/news/ethicsguidelines-trustworthy-ai. Downloaded: 12 September 2019.

European Commission (2019b): Artificial intelligence: Commission takes forward its work on ethics guidelines. Press release. https://ec.europa.eu/commission/presscorner/detail/ en/IP_19_1893. Downloaded: 22 May 2019.

EBF (2018): European Banking Federation: Financing the Europe of Tomorrow. A vision for European policy makers, banks in a changing world. https://www.ebf.eu/wp-content/ uploads/2018/09/Financing-the-Europe-of-tomorrow-a-vision-for-policymakers-banksand-markets-in-a-changing-world-September-2018.pdf. Downloaded: 8 September 2019.

Fáykiss, P. - Papp, D. - Sajtos, P. - Tőrös, Á. (2018): Regulatory Tools to Encourage FinTech Innovations: The Innovation Hub and Regulatory Sandbox in International Practice. Financial and Economic Review, 17(2): 43-67. http://doi.org/10.25201/FER.17.2.4367

FSB (2019): Financial Stability Board: FinTech and market structure in financial services: Market developments and potential financial stability implications. 14 February. https:// www.fsb.org/wp-content/uploads/P140219.pdf. Downloaded: 22 May 2019.

Fleming, S. (2018): We no longer have faith in technology to solve global issues. World Economic Forum. https://www.weforum.org/agenda/2018/10/digital-distrust-we-relosing-faith-in-technology-to-solve-the-world-s-problems/. Downloaded: 22 May 2019.

Guillén, M.F. - Reddy, S. (2018): We know ethics should inform Al. But which ethics? https:// www.weforum.org/agenda/2018/07/we-know-ethics-should-inform-ai-but-which-ethicsrobotics/. Downloaded: 22 May 2019. 
Hungarian Banking Association (2015): Aktualizált Magatartási Kódex a lakosság részére hitelt nyújtó pénzügyi szervezetek ügyfelekkel szembeni tisztességes magatartásáról (Updated Code of Conduct about fair treatment of customers for financial institutions that lend to the public). https://docplayer.hu/814270-Aktualizalt-magatartasi-kodex-alakossag-reszere-hitelt-nyujto-penzugyi-szervezetek-ugyfelekkel-szembeni-tisztessegesmagatartasarol.html. Downloaded: 22 May 2019.

Kerényi, Á. - Molnár, J. (2017): The Impact of the Fintech Phenomenon - Radical Change Occurs in the Financial Sector? Financial and Economic Review, 16(3): 32-50. http://doi. org/10.25201/FER.16.3.3250

Kerényi, Á. - Müller, J. (2019): Brave New Digital World? - Financial Technology and the Power of Information. Financial and Economic Review, 18(1): 5-32. http://doi. org/10.33893/FER.18.1.532

Koslowski, P. (2011): The Ethics of Banking. Conclusions from the Financial Crisis. Springer. https://doi.org/10.1007/978-94-007-0656-9

Loeger, H. (2019): Austria may launch Fintech Regulatory Sandbox. https://www.devereaustria.eu/news/Austria-may-launch-Fintech-Regulatory-Sandbox. Downloaded: 22 May 2019.

MNB (2019): Nemzetközi Fintech hatósági csoporthoz csatlakozott az MNB (The Magyar Nemzeti Bank has joined the international Fintech regulatory group). MNB Press Release, 31 January 2019. https://www.mnb.hu/sajtoszoba/sajtokozlemenyek/2019evi-sajtokozlemenyek/nemzetkozi-fintech-hatosagi-csoporthoz-csatlakozott-az-mnb. Downloaded: 22 May 2019.

Ritter, Á. (1879): Müszaki mechanika (Technical mechanics). Franklin Társulat, Budapest.

Villa, J. (2015): Ethics in Banking. The Role of Moral Values and Judgements in Finance. Palgrave Macmillan. 